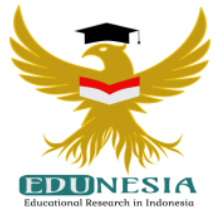

\title{
Penerapan Metode Simulasi untuk Meningkatkan Hasil Belajar Psikomotor Siswa Pada Mata Pelajaran Pendidikan Jasmani Olahraga dan Kesehatan (PJOK)
}

\author{
Leni Lutfiani', Asis Saefuddin ${ }^{2}$, Dede Rohaniawati ${ }^{3}$ \\ 1,2,3 Pendidikan Guru Madrasah Ibtidaiyah, UIN Sunan Gunung Djati Bandung, Indonesia \\ ${ }^{1}$ Corresponding Email: lenilutfiani24@gmail.com, Phone Number : 0853 xxxx xxxx
}

\author{
Article History: \\ Received: Sept 09, 2020 \\ Revised: Sept 24, 2020 \\ Accepted: Sept 25, 2020 \\ Published: Jan 01, 2021
}

\section{Keywords:}

Learning Psikomotor, PJOK, Simulation Method.

\section{Kata Kunci:}

Belajar Psikomotor, Metode Simulasi, PJOK.

\section{How to cite:}

Lutfiani, L., Saefuddin, A., \& Rohaniawati, D. (2021). Penerapan Metode Simulasi untuk Meningkatkan Hasil Belajar Psikomotor Siswa Pada Mata Pelajaran Pendidikan Jasmani Olahraga dan Kesehatan (PJOK). Edunesia : Jurnal Ilmiah Pendidikan, 2 (1): 55-64

This is an open access article unde the $C C-B Y-N C-N D$ license

\begin{abstract}
This study aims to determine the increase in student psychomotor learning outcomes in MIS Bangsal Ciamis Regency by using the simulation method. The approach used in this study is a qualitative and quantitative approach or mix method. This type of research is classroom action research. The research implementation design contained planning, implementation, observation and reflection. Data collection techniques used observation, interviews, performance tests, and documentation studies. The purpose of this study was to determine the psychomotor learning outcomes of students before using the simulation psychomotor learning outcomes of students after using the simulation method. Based on the results of research in the pre-cycle students' psychomotor learning outcomes were $39.13 \%$ with a very poor category, after using the simulation method the psychomotor learning outcomes of students in the first cycle were $52.17 \%$ in the very poor category, while in the second cycle students experienced the increase was in the medium category, namely $73.91 \%$. From these data it can be concluded that by using the simulation method student learning outcomes have increased.
\end{abstract}

Abstrak: Penelitian ini bertujuan untuk mengetahui peningkatan hasil belajar psikomotor siswa di MIS Bangsal Kabupaten Ciamis dengan menggunakan metode simulasi. Pendekatan yang digunakan pada penelitian ini adalah pendekatan kualitatif dan kuantitatif atau mix method. Jenis penelitian yang digunakan adalah penelitian tindakan kelas. Rancangan pelaksanaan penelitian terdapat perencanaan, pelaksanaan, observasi dan refleksi. Teknik pengumpulan data menggunakan observasi, wawancara, tes unjuk kerja, dan studi dokumentasi. Tujuan penelitian ini adalah untuk mengetahui hasil belajar psikomotor siswa sebelum menggunakan metode simulasi, proses pembelajaran mata pelajaran PJOK dengan menggunakan metode simulasi, dan hasil belajar psikomotor siswa setelah menggunakan metode simulasi. Berdasarkan hasil penelitian pada pra siklus hasil belajar psikomotor siswa sebesar 39,13\% dengan kategori sangat kurang, setelah menggunakan metode simulasi hasil belajar psikomotor siswa pada siklus I sebesar 52,17\% dengan kategori sangat kurang, sedangkan pada siklus II hasil belajar psikomotor siswa mengalami peningkatan berada pada kategori sedang yaitu $73,91 \%$. Dari data tersebut dapat disimpulkan bahwa dengan menggunakan metode simulasi hasil belajar siswa mengalami peningkatan. 


\section{A. Pendahuluan}

Dewasa ini perkembangan ilmu pengetahuan dan teknologi sangat pesat tentu semua itu dirasakan oleh semua orang. Salah satu kelebihan IPTEK saat ini banyak terciptanya peralatan canggih untuk mempermudah membantu pekerjaan aktivitas manusia seperti, alat komunikasi, peralatan rumah tangga, game online dan lain sebagainya. Sedangkan kekurangannya mengakibatkan gerak sehari-hari menjadi kurang sehingga banyak yang terjangkit berbagai penyakit, mudah lelah dan malas untuk melakukan gerak. Munculnya game online saat ini pada dasarnya di mainkan dengan mengandalkan jari saja dan untuk memainkannya tidak banyak menguras tenaga sehingga membuat betah dan nyaman saat memainkannya. Berbeda dengan permainan tradisional yang bermainnya memerlukan aktivitas fisik yang menguras tenaga, dan juga di mainkan di tempat terbuka dan luas seperti lapangan, dan pekarangan rumah yang luas (Saleh, 2017).

Permasalahan tersebut menciptakan berbagai masalah utama salah satunya menghantui pendidikan jasmani karena terjadinya perubahan nilai budaya. Perubahan yang dimaksud adalah perubahan gerak. Terjadinya perubahan gerak yang biasanya bergerak aktif menjadi pasif atau bahkan sangat malas bergerak. Hal tersebut terbukti dari hasil survei yang dilakukan oleh tim pengembang Sport Development Index bahwa kebugaran jasmani pelajar di seluruh Indonesia hasilnya tidak ada yang baik sekali atau 0 $\%$, katagori baik hanya 5,66 \%, sedang 37,66 \%, kurang 45,97 \%, dan kurang sekali 10,71 \%, perihal ini WHO pada tahun 2004 mengatakan apabila dapat dicegah lebih awal, maka akan mengurangi angka kematian sebesar 2 juta orang atau 5479 orang yang meninggal dunia akibat penyakit hypokinetik setiap tahunnya (Sceisarriya, 2016) .

Hal ini juga menjadi penyebab salah satu kematian di dunia, WHO memprediksi pada tahun 2020 sebanyak $73 \%$ kematian disebabkan oleh penyakit yang tidak menular, atau sebanyak $60 \%$ disebabkan rendahnya kebugaran jasmani. Sekarang ini banyak penyakit yang menyerang bukan kepada kalangan dewasa dan orang tua saja, tetapi juga menyerang anak-anak seperti sakit jantung, mudah lelah, dan sebagainya. Hal tersebut diakibatkan karena kurangnya kebugaran jasmani, kurangnya olahraga, tidak mengatur pola hidup sehat (Sceisarriya, 2020).

Pendidikan adalah usaha untuk mengembangkan Sumber Daya Manusia (SDM) melalui kegiatan belajar mengajar, tujuan utama dalam pembelajaran menciptakan suasana belajar yang menyenangkan, dapat menarik minat, antusias, serta dapat memotivasi siswa senantiasa belajar dengan baik dan mencapai tujuan yang optimal (Purwanto, 2010).

Pendidikan jasmani pada hakikatnya kegiatan peserta didik untuk meningkatkan keterampilan motorik dan nilai-nilai fungsional yang diantaranya mencakup kognitif, afektif dan psikomotor, sehingga melalui kegiatan jasmani peserta didik dapat menghasilkan perubahan yang signifikan dalam hal kepribadian, meningkatkan mental, dan juga dalam bersosial di lingkungannya. Bukan hanya itu melakukan aktivitas jasmani secara teratur dapat merangsang perkembangan dan pertumbuhan kualitas fisik dan psikis yang baik dan seimbang (Depdiknas, 2003).

Dalam melakukan mata pelajaran PJOK banyak melibatkan aktivitas fisik atau gerak tubuh dan juga tidak lepas dari kata bermain. Bermain adalah kegiatan yang dilakukan secara ikhlas tanpa ada paksaan karena bermain merupakan hal yang disenangi oleh anak di usia 6-12 tahun. Pada hakikatnya anak senang bermain karena dengan 
bermain pertumbuhan dan perkembangan daya tubuh anak dapat berkembang dengan baik. Di masa usia ini diperlukan stimulus yang baik karena di usia 6-12 tahun semua yang diajarkan akan menempel secara permanen, otak anak pada usia ini bekerja $80 \%$ yang ditandai dengan cepat pada perubahan fisik, kognitif, emosional, sosial dan sebagainya (Rahman, 2017).

Sama halnya yang di katakan oleh Harsono (2015) sesuai dengan karakter anak 7-12 tahun cenderung lebih suka bermain, karena bermain merupakan suatu aktivitas yang dilakukan dengan secara sukarela atau tidak ada paksaan, dengan bermain siswa akan melakukan banyak bergerak, seperti berlari, melompat, mendorong,dan lain sebagainya, sehingga dapat memberikan stimulus yang baik untuk mengembangkan dan mendorong naluri guna merangsang perkembangan keterampilan fisik maupun mental.

Indikator hasil belajar psikomotorik merupakan gambaran tingkat kemampuan yang harus dicapai oleh siswa terhadap mata pelajaran yang ditempuhnya. Berikut adalah indikator hasil belajar ranah psikomotor menurut Harrow yang di kutip oleh Asrul (2014) adalah:

a. Imitasi adalah kemampuan melakukan kegiatan sederhana dan sama persis dengan yang dilihat atau diperhatikan sebelumnya. Contohnya, siswa dapat memukul bola dengan tepat karena pernah melihat atau memperhatikan hal yang sama sebelumnya.

b. Manipulasi adalah kemampuan melakukan kegiatan sederhana yang belum pernah dilihat tetapi berdasarkan pada pedoman atau petunjuk saja atau kemampuan dalam memodifikasi suatu keterampilan. Sebagai contoh, siswa dapat memukul bola dengan tepat hanya berdasarkan pada petunjuk guru atau teori yang dibacanya.

c. Presisi adalah kemampuan melakukan kegiatan-kegiatan yang akurat sehingga mampu menghasilkan produk kerja yang tepat atau kemampuan yang memperlihatkan adanya kecakapan dalam melakukan aktivitas dengan tingkat akurasi yang tinggi. Contoh, siswa dapat mengarahkan bola yang dipukulnya sesuai dengan target yang diinginkan.

d. Artikulasi adalah kemampuan melakukan kegiatan yang kompleks dan tepat sehingga hasil kerjanya merupakan sesuatu yang utuh atau kemampuan dalam melakukan aktivitas secara terkoordinasi dan efesien. Sebagai contoh, siswa dapat mengejar bola kemudian memukulnya dengan cermat sehingga arah bola sesuai dengan target yang diinginkan. Dalam hal ini, siswa sudah dapat melakukan tiga kegiatan yang tepat, yaitu lari dengan arah dan kecepatan tepat serta memukul bola dengan arah yang tepat pula.

e. Naturalisasi adalah kemampuan melakukan kegiatan secara refleks atau mampu melakukan gerakan tertentu secara spontan tanpa berpikir lagi cara melakukannya dan urutannya, yakni kegiatan yang melibatkan fisik saja sehingga efektivitas kerja tinggi. Sebagai contoh tanpa berpikir panjang siswa dapat mengejar bola kemudian memukulnya dengan cermat sehingga arah bola sesuai dengan target yang diinginkan.

Metode simulasi adalah rancangan pembelajaran yang bersifat praktis guna mengembangkan skill baik keterampilan mental ataupun keterampilan fisik/teknis. Metode pembelajaran ini dapat membawa siswa pada situasi yang seakan-akan benar karena adanya kesulitan dan ketidak mungkinan untuk melakukan hal yang sebenarnya. Metode ini membentuk siswa dengan cara melakukan prtaktek atau suatu proses keadaan yang sebenarnya atau state of 
affrais, membantu bersosialisasi dengan keadaan nyata, mengasah keterampilan, kepekaan dan berfikir untuk mengambil suatu keputusan (Shoimin, 2017).

Adapun langkah-langkah proses pembelajaran menurut Majid (2013) dibagi menjadi tiga tahap, yaitu sebagai berikut:

1. Tahap persiapan simulasi

1) Menentukan topik serta tujuan yang akan dicapai

2) Memberikan penjelasan yang akan dilaksanakan

3) Menentukan banyaknya siswa

4) Memberikan kesempatan untuk bertanya sebelum dimulai

2. Tahap pelaksanaan simulasi/tindakan simulasi

1) Dimainkan setiap siswa

2) Siswa yang belum mendapat giliran memerhatikan dengan seksama

3) Memberikan bantuan arahan yang mendapat kesulitan

3. Tahap penutup/evaluasi simulasi

1) Melakukan diskusi

2) Memberikan kesimpulan dan penguatan

Tukirana (2011) menyatakan kelebihan metode simulasi, adalah :

a. Memberikan kesenangan kepada siswa dalam melakukan simulasi

b. Dalam melakukan simulasi guru harus bisa mengembangkan aktivitas yang menyenangkan

c. Tidak memerlukan masalah yang sebenarnya

d. Memberikan penjelasan hal-hal yang tidak jelas

e. Komunikasi yang biasa

f. Memberikan interaksi antar siswa dengan baik

g. Memberikan hal yang baik bagi siswa yang kurang cakap

h. Menumbuhkan berfikir kritis.

Menurut Shoimin (2017) kelemahan metode simulasi adalah:

a. Pengalaman yang didapat dari metode simulasi tidak selalu tepat dengan yang ada dilapangan

b. Memerlukan alat-alat khusus

c. Pembelajaran yang kurang persiapan sehingga kurang baik dan di jadikan alat hiburan sehingga tujuan yang telah direncanakan tidak

d. Dalam melakukan simulasi tidak terhindar dari faktor pisikologis seperti malu dan tidak berani sehingga memperlambat dalam mempraktikan metode simulasi.

\section{B. Metode}

Metode penelitian yang digunakan adalah metode Penelitian Tindakan Kelas (PTK), Model penelitian menggunakan model Kemmis dan Mc. Taggart, model ini dikenalkan oleh Kurt Lewin selanjutnya dikembangkan lagi oleh Kemmis dan Mc. Taggart, sehingga sampai saat ini disebut juga dengan model penelitian Kemmis dan Mc. Taggart. Pada model penelitian ini pelaksanaan digabungkan dengan observasi karena kegiatan tersebut tidak dapat dipisahkan sehingga harus dilakukan bersama-sama, ketika berlangsungnya kegiatan yang dilakukan maka harus disegerakan dengan kegiatan observasi. Bila diamati dengan seksama model ini berupa untaian perangkat dengan satu perangkat yang terdiri dari empat komponen yaitu, perencanaan, tindakan, observasi, dan refleksi. Perangkat-perangkat tersebut dipandang sebagai satu siklus (Depdiknas, 2005). 
Penelitian ini dilakukan selama dua siklus, yang terdiri dari empat tahapan yaitu, perencanaan, pelaksanaan, observasi dan refleksi. Salahudin (2015) menyatakan PTK adalah salah satu upaya yang dilakukan guru guna memperbaiki dan meningkatkan pembelajaran yang dilakukan di dalam kelas. Untuk mengetahui lebih jelas mengenai metode PTK menurut Kemmis dan Mc. Taggart, dapat dilihat pada desain penelitian berikut.

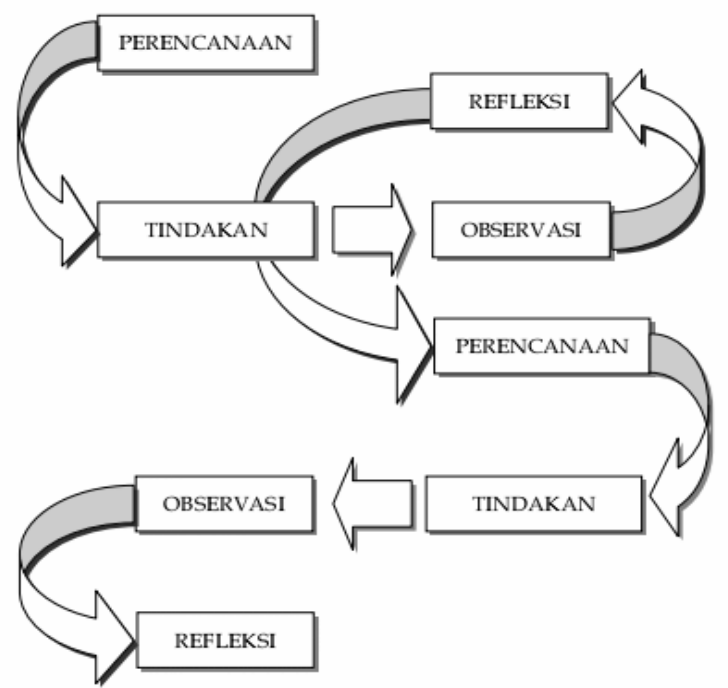

Gambar 1. Desain penelitian

Pendekatan yang dilakukan pada penelitian menggunakan pendekatan mix method atau pendekatan kuantitatif dan pendekatan kualitatif. Pendekatan kuantitatif yaitu analisis data bersifat angka dan dihitung menggunakan statistik dengan tujuan untuk menguji hipotesis yang telah ditetapkan serta untuk mengetahui informasi selama pembelajaran PJOK, data ini diambil dari hasil belajar melalui tes unjuk kerja dan lembar observasi aktivitas belajar siswa, pengambilan data ini dilakukan secara random (Sugiyono, 2015). Sedangkan pendekatan kualitatif merupakan pendekatan yang digunakan untuk meneliti pada obyek yang alamiah, analisis data ini berupa deskripsi untuk mengetahui gambaran proses pembelajaran, data ini diambil melalui studi dokumentasi dan lembar observasi. (Siyoto, 2015).

Sumber data pada penelitian ini meliputi data primer dan data sekunder. Data primer adalah siswa kelas IV MIS Bangsal Kabupaten Ciamis yang berjumlah 23 orang, 9 siswa perempuan dan 14 siswa laki-laki. Sedangkan data sekunder adalah guru wali kelas dan guru mata pelajaran PJOK kelas IV.

Teknik pengumpulan data pada penelitian menggunakan observasi, tes unjuk kerja, wawancara dan studi komentasi. Observasi merupakan sebuah cara atau kumpulan bahan-bahan data untuk dijadikan deskripsi yang dilakukan dengan mengamati dan pencatatan secara teratur dan kenyataan yang sedang terjadi (Gunawan, 2016). Dalam penelitian ini peneliti menggunakan tes berupa unjuk kerja atau tes praktik, unjuk kerja merupakan penilaian yang dilakukan dengan mengamati kegiatan peserta didik dalam melakukan sesuatu (Pujiastuti, 2013). Wawancara atau interview adalah percakapan antara dua orang atau lebih antara narasumber dan pewawancara, tujuannya untuk mendapatkan informasi yang tepat dan terpercaya dari narasumber dengan mengajukan 
beberapa pertanyaan (Sudjana, 2017). Studi Dokumentasi merupakan teknik pengumpulan data dengan cara mendistribusikan dokumen untuk mendapatkan data atau informasi yang berkaitan dengan masalah yang dibahas, seperti gambar atau foto, biodata sekolah dan yang lainnya.

\section{Hasil dan Pembahasan}

\section{Hasil Belajar Psikomotor Siswa pada Mata Pelajaran PJOK sebelum Menggunakan Metode Simulasi}

Hasil belajar psikomotor siswa sebelum menggunakan metode simulasi peneliti mengambil dari studi pendahuluan dengan cara meminta daftar nilai praktek siswa kepada guru mata pelajaran PJOK sebelum di akumulasikan dengan kegiatan-kegiatan yang lainnya dan juga melakukan wawancara terkait pembelajaran pada mata pelajaran PJOK. Setelah mendapatkan nilai praktek siswa, maka peneliti menganalisis nilai tersebut untuk mengetahui hasil belajar psikomotor siswa di kelas IV MIS Bangsal yang berjumlah 23 orang.

Berdasarkan studi dokumentasi dan wawancara kepada guru mata pelajaran tersebut yang dilakukan peneliti bahwasanya masih terdapat banyak siswa yang kurang memperhatikan saat pembelajaran berlangsung dan kurangnya peran aktif siswa dalam proses pembelajaran. Hasil perolehan prasiklus ini terdapat 9 orang siswa yang tuntas dan 14 orang siswa yang belum tuntas. Dalam hal ini berarti kemampuan belajar psikomotor siswa pada mata pelajaran PJOK siswa masih berada di bawah rata-rata. Oleh karena itu, peneliti mencoba menerapkan metode simulasi pada pembelajaran PJOK yang bertujuan untuk memudahkan siswa dan meningkatkan kemampuan hasil belajar psikomotornya.

Untuk mengetahui hasil belajar psikomotor siswa pada pra siklus dapat dilihat pada gambar 2 .

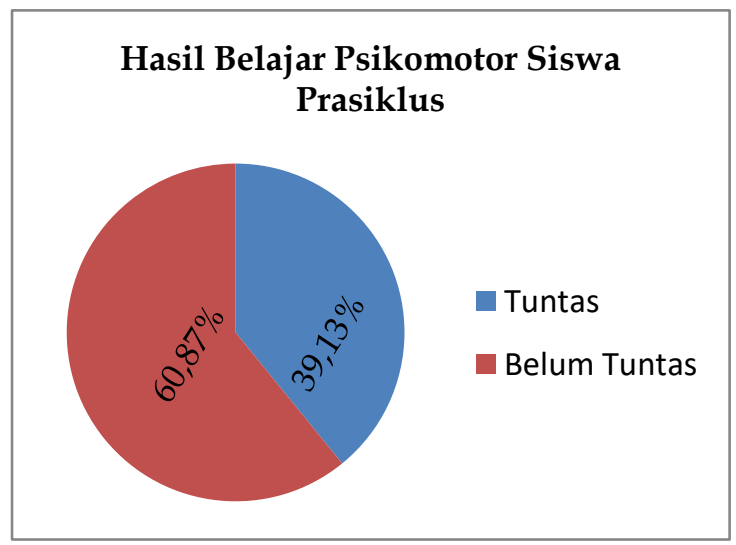

Gambar 2. Hasil Belajar Psikomotor Siswa Prasiklus

Berdasarkan dari gambar tersebut jumlah siswa yang tuntas sebanyak 9 orang, sedangkan 14 siswa lainnya belum tuntas. Apabila di presentasikan yang tuntas sebesar $39,13 \%$ dan yang belum tuntas sebesar $60,87 \%$. Kurangnya hasil belajar siswa pada prasiklus ini disebabkan oleh beberapa faktor, salah satunya guru tidak menggunakan metode yang menyenangkan, tidak menggunakan media yang mendukung dalam melakukan permainan, saat menjelaskan materi dilakukan di lapang sehingga siswa tidak fokus yang guru jelaskan. Melihat kondisi tersebut maka pada siklus I dan II dilakukan perbaikan dengan menggunakan metode simulasi pada mata pelajaran PJOK. Diharapkan 
metode tersebut bisa memperbaiki hasil belajar psikomotor siswa pada mata pelajaran PJOK.

\section{Proses Pembelajaran PJOK di Kelas IV MIS Bangsal Kabupaten Ciamis dengan Menggunakan Metode Simulasi}

Penelitian ini dilakukan selama dua siklus dengan menggunakan metode penelitain model Kemmis dan Mc. Taggart. Pada tahap ini proses pembelajaran pada mata pelajaran PJOK dengan menggunakan metode simulasi yang bertujuan untuk meningkatkan hasil belajar psikomotor siswa. Kegiatan belajar siswa yang dimaksud pada proses pembelajaran dengan menggunakan metode simulasi adalah bagaimana respon siswa terhadap pembelajaran yang guru bawakan. Sedangkan aktivitas mengajar guru disesuaikan dengan RPP yang telah dirancang sebelumnya.

Untuk mengetahui peningkatan aktivitas mengajar guru dan peningkatan aktivitas siswa pada siklus I dan II dapat dilihat pada gambar 3 dan 4.

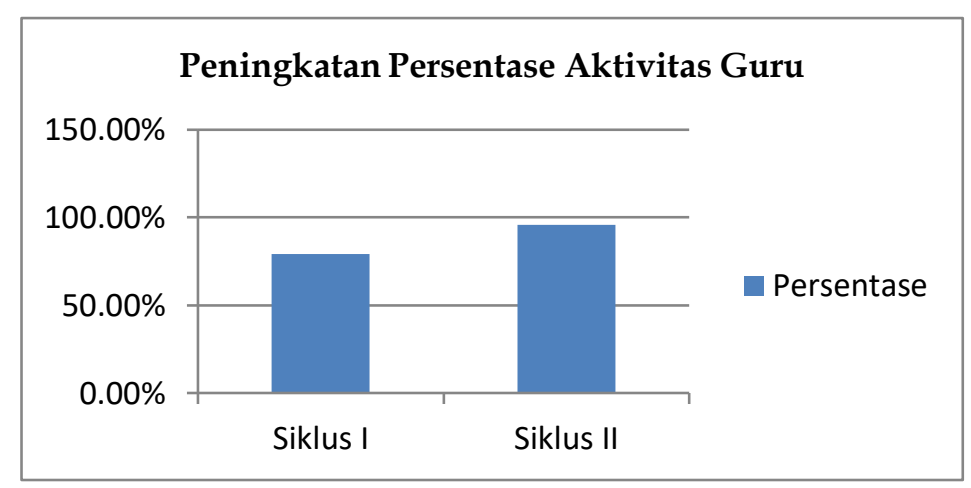

Gambar 3. Peningkatan Persentase Aktivitas Guru

Dapat dilihat pada gambar 3 hasil aktivitas guru mengalami peningkatan setiap siklusnya. Penerapan metode simulasi pada materi permainan lempar tangkap bola kecil sudah diterapkan dengan baik. Karena semua langkah-langkah yang guru ajarkan sudah dilakukan dengan baik sesuai dengan RPP yang telah dibuat sebelumnya, sehingga aktivitas mengajar guru. Aktivitas guru pada siklus I memperoleh rata-rata sebesar 79,17\% dengan kriteria baik, kemudian pada siklus II mengalami peningkatan dengan persentase rata-rata sebesar $95,83 \%$ dengan kriteria sangat baik.

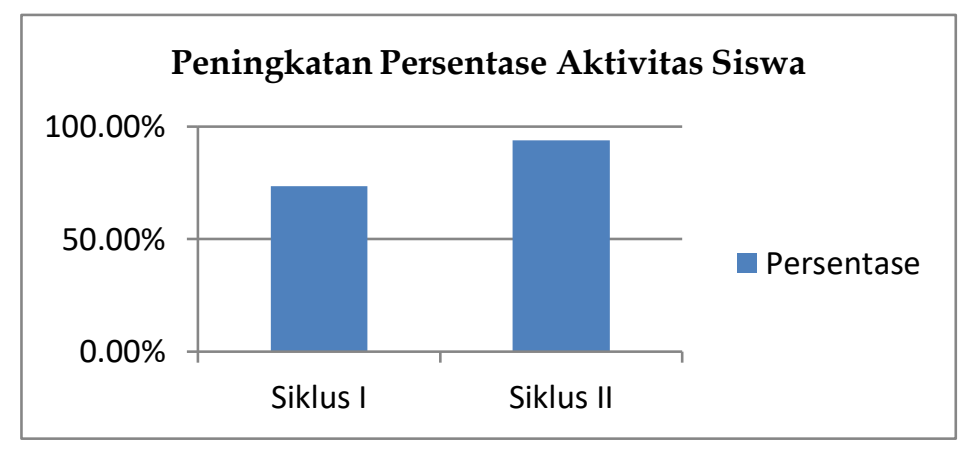

Gambar 4. Peningkatan Persentase Aktivitas Siswa 
Pada gambar 4 belajar siswa mengalami kenaikan selama proses pembelajaran setiap siklusnya, persentase aktivitas belajar siswa pada siklus I mendapatkan persentase rata-rata sebesar 73,61\% dengan kategori baik, dan pada siklus II sebesar $94 \%$ dengan kategori sangat baik.

\section{Hasil Belajar Psikomotor Siswa pada Mata Pelajaran PJOK Kelas IV MIS Bangsal Kabupaten Ciamis Setelah Menggunakan Metode Simulasi.}

Berdasarkan hasil analisis hasil belajar psikomotor siswa pada mata pelajaran PJOK kelas IV MIS Bangsal Kabupaten Ciamis mengalami peningkatan di setiap siklusnya. Pada siklus I siswa memperoleh rata-rata sebesar 73,26\%, sedangkan pada siklus II 77,61\%. Peningkatan setiap siklus tersebut bisa dilihat pada gambar dibawah ini.

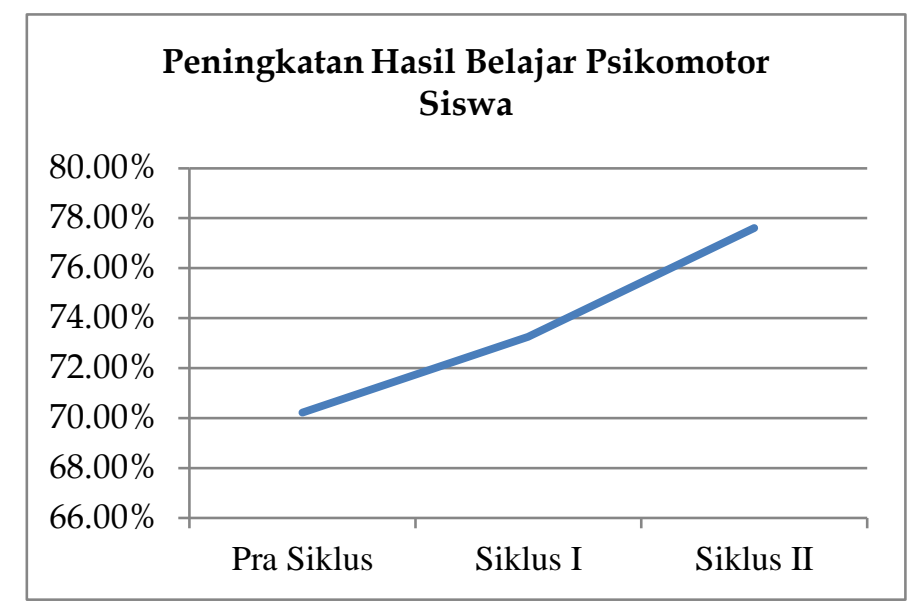

Gambar 5. Peningkatan Hasil Belajar Psikomotor Siswa

Dapat dilihat pada gambar 5 terjadinya kenaikan pada setiap siklusnya, hal itu dirasakan karena siswa cenderung lebih aktif ketika proses pembelajaran, dan juga aktivitas mengajar guru dengan menggunakan metode simulasi dilakukan secara baik sesuai dengan RPP yang telah dirancang sebelumnya. Karena metode ini penyajian pelajarannya dengan cara memperagakan atau menirukan tentang proses situasi tertentu. Berdasarkan data yang telah disajikan, maka metode simulasi dapat meningkatkan hasil belajar psikomotor siswa pada mata pelajaran PJOK. Maka dari itu dalam pembelajaran mata pelajaran PJOK cocok menggunakan metode simulasi.

\section{Kesimpulan}

Berdasarkan hasil penelitian tentang penggunaan metode simulasi pada mata pelajaran PJOK untuk meningkatkan hasil belajar psikomotor siswa terbukti mengalami peningkatan. Hasil belajar psikomotor siswa pada mata pelajaran PJOK sebelum menggunakan metode simulasi pada kelas IV MIS Bangsal Kabupaten Ciamis nilai rataratanya sebesar $70,22 \%$. Karena dalam proses pembelajaran guru menggunakan metode yang konvensional dan tidak menggunakan media sebagai alat bantu dalam pembelajaran atau hanya menggunakan media yang seadanya, dan juga guru dalam menjelaskan materi langsung dilakukan di luar kelas, sehingga siswa tidak mengerti dengan materi yang guru jelaskan dan tidak memperhatikan guru karena banyak objek yang siswa lihat sehingga 
menarik perhatiannya ketika di luar kelas. Proses penggunaan metode simulasi dalam mata pelajaran PJOK kelas IV MIS Bangsal Kabupaten Ciamis terlaksana dengan baik. Hal ini dapat terlihat dari meningkatkan hasil aktivitas guru dan siswa selama proses pembelajaran. Aktivitas guru pada siklus I mencapai presentase 79,17\%, siklus II sebesar 95,8\%. Begitupun aktivitas siswa pada siklus I mencapai presentase 73,61\%, siklus II mencapai presentase $94 \%$. Hasil belajar psikomotor siswa pada mata pelajaran PJOK kelas IV MIS Bangsal Kabupaten Ciamis mengalami peningkatan yang baik dari siklus I sampai siklus II, terlihat dari nilai rata-rata belajar siswa siklus I mencapai presentase $73,26 \%$, siklus II mencapai presentase $77,61 \%$.

\section{Daftar Pustaka}

Asrul, d. (2014). Evaluasi Pembelajaran. Medan : Perdana Mulya Sarana.

Depdiknas. (2005). "Penulisan Karya Ilmiah" dalam Materi Pelatihan Terintegrasi Jilid 3. Jakarta: Depdiknas Dirjen Pendidikan Dasar dan Mengengah Direktorat Pendidikan Lanjutan Pertama.

Harsono. (2015). Kepelatihan Olahraga. Bandung : PT. Remaja Rosdakarya.

Majid, A. (2013). Strategi Pembelajaran. Bandung: Remaja Rosdakarya Offset.

Pujiastuti, L. (2013). Penerapan Model Pembelajaran Kooperatif Teknik Tari Bambu Pada Pembelajaran Berbicara. Repository.upi.edu, 37.

Purwanto. (2010). Media Pembelajaran. Jakarta: Raja Grafindo Persada.

Rahman, A. Y. (2017, April). The Different Effect Of Playing and Training Learning Approach On The Ability Of The Straddle Style High Jump Of The 5th Grade Male Students Of Djamaatul Ichwan Elementary School Surakarta Academic Year 2013/2014. In The 4th International Conference On Physical Education, Sport and Health (ISMINA) and Workshop.Enhancing Sport, Pshycal Activity, and Health Promotion For A Better Quality Of Life, p. 114.

Salahudin, A. (2015). Penelitian Tindakan Kelas. Bandung: CV Pustaka Setia.

Saleh, Y. T. (2017). Model Permainan Tradisional "Boy-Boyan" Untuk Meningkatkan Perkembangan SisialL Anak SD. ELSE (Elementary School Education Journal): Jurnal Pendidikan dan Pembelajaran Sekolah Dasar, 127-128.

Sceisarriya, V. M. (2016). Problematika Pelaksanaan Pendidikan Jasmani Di Sekolah Dasar . Pendidikan Olahraga, Pascasarjana, Universitas Negeri Malang, 154.

Sceisarriya, V. M. (2020). Problematika Pelaksanaan Pendidikan Jasmani di Sekolah Dasar . Prosiding Seminar Nasional Profesionalisme Tenaga Profesi PJOK, 154. 
Shoimin. (2017). Model Pembelajaran Inovatif Kurikulum 2013. Yogyakarta: Ar-Ruzz Media.

Shoimin, A. (2014). Model Pembelajaran Inovatif dalam Kurikulum 2013. Yogyakarta: Ar-Ruzz Media.

Siyoto. (2015). Dasar Metodologi penelitian. Yogyakarta: Literasi Media Publishing.

Sugiyono. (2015). Metode Penelitian Pendidikan. Bandung: PT. Remaja Rosdakarya.

Tukirana Taniredja, d. (2011). Model-Model pembelajaran Inovatif. Bandung: Alfabeta. 